\title{
Sciendo
}

DOI: $10.1515 /$ sspjce-2019-0015

\section{Experimental determination of the efficiency of the solar collector integrated into the light transparent building facade}

\author{
Vasyl Zhelykh' ${ }^{1}$, Peter Kapalo², Stepan Shapoval ${ }^{1}$, Iryna Venhryn' ${ }^{1}$, Khrystyna Kozak ${ }^{1}$ \\ 1 National University "Lviv Polytechnic", Institute of Building and Environmental Engineering, \\ Department 'Heat and Gas Supply and Ventilation', Lviv, Ukraine \\ e-mail: iryna.i.venhryn@lpnu.ua \\ ${ }^{2}$ Technical University of Košice, Faculty of Civil Engineering, Institute of Architectural Engineering \\ e-mail: peter.kapalo@tuke.sk
}

\begin{abstract}
One of the most promising energy sources is solar energy, which is confirmed by the growth in the development of renewable energy for European countries. The main goal of research is to design and implement the latest energy systems for passive buildings using renewable energy. In this paper is documented the optimal operation stages of the solar heat supply system were investigated with recommendations for further development of the design and construction of passive buildings in Ukraine South.
\end{abstract}

Key words: solar collector, building, facade, solar heating system, thermal energy

\section{Introduction}

Solar radiation is an inexhaustible source of renewable clean energy. The flow of solar radiation coming to the earth's surface is uneven. The amount of solar radiation entering on the earth's surface ranges from $\approx 3000 \mathrm{MJ}$ to $\approx 8000 \mathrm{MJ}$ per $1 \mathrm{~m}^{2}$. Taking into account this range of solar energy input, installations that convert solar radiation into thermal or electrical energy are used. Such installations are solar collectors. Previous studies have found that the amount of solar energy entering on the territory of Ukraine is generally sufficient for its use [1]. This amount of solar radiation is greater for the territory of Europe.

Solar energy could be used efficiently in the immediate vicinity of the consumer, that is, without transmitting energy over a significant distance [2]. For the needs of the consumer's heat supply must be used heat supply system. However, if the system contains a solar collector, it can be considered as a solar heat supply system (SHSS). In addition, to receiving solar radiation from space to the surface of the solar collector, it is recommended to take into account the albedo of solar radiation $[3,4]$. The albedo of solar radiation depends on the 
nature of the area and its geographical latitude, where the solar collector is located. In paper [5] was obtained albedo data for various surfaces based on NASA operational data from June 11 to June 26, 2006. For example, the average albedo values for the latitudes of Ukraine are higher than the planetary value around $30 \%$ and make up $38 \%$.

Solar collectors could work both independently and as part of traditional energy facilities in heating and air conditioning systems, for additional supply to boilers and so on. However, it is necessary to choose the mode of operation of the solar collector depending on its location in the SHSS. The traditional design of the flat solar collector consists of an insulating material, circulation pipelines, and a heat-receiving surface (absorber). Such designs of solar collectors allow to get a heat carrier with a temperature up to $70{ }^{\circ} \mathrm{C}$.

A new direction in designing of solar collectors can be considered their integration into building fences.

The argument for integrating solar collectors into the building structure was presented at a conference in Germany [6]. It was established that solar collectors with proper design are no less effective than heat pumps. They also stressed the need to take measures to reduce the cost of the system by selecting solar collectors in building structures during the design and construction of facades and roofs which confirms the need for further research.

Today, energy-efficient architectural construction in combination with solar heat supply systems is increasingly being considered [7]. For instance, the use of renewable energy in relation to glass and solar architecture. A more detailed analysis of solar houses is carried out in the literature [8,9]. It is advisable to take into account the technical and economic indicators of the construction of a new building with different parameters of hardness around it [10]. The building spot, in particular the building seal, helps to reduce the specific heat loss of the house. In particular, those homes that have interior space are more energy-efficient [7]. In Poland, a law on thermoregulation was adopted, the main objectives of which were to increase the normative indicators of annual heat consumption of buildings and increase the requirements for indicators of heat transfer coefficients of building fencing elements [11]. The main goal of research in a scientific and technical project $[12,13,21]$ are to design and implement the latest energy systems for passive buildings using renewable energy. The optimal operation stages of the solar heat supply system were investigated with recommendations for further development of the design and construction of passive buildings. It is also worth paying attention to labour [14], which describes the principles of designing energy efficient buildings in the Ukraine South.

\section{Objectives the Formulation of the Problem}

Many papers believe that the energy sector should play a central role in any transition to low carbon consumption since it is the single largest source of carbon emissions. Data shows that demand for electricity increased by $3.7 \%$, which is one of the highest growth rates in the last 20 years. In terms of offers, the increase in electricity production was driven by renewable energy sources, which grew by $14.5 \%$, providing about a third of the growth. For European countries in the statistics described in [15] data on the development of renewable energy from 2010 to 2018 in millions of tons of oil equivalent are provided. On the basis of these data, the development of renewable energy was predicted to 2030 and the possibility of reaching 300 million tons of oil equivalent for the renewable energy was established (Fig. 1). The sharp 
growth of this type of energy in Europe is due primarily to the deterioration of installations that operate from traditional energy as a result of energy efficiency programs that are developed by European governments.

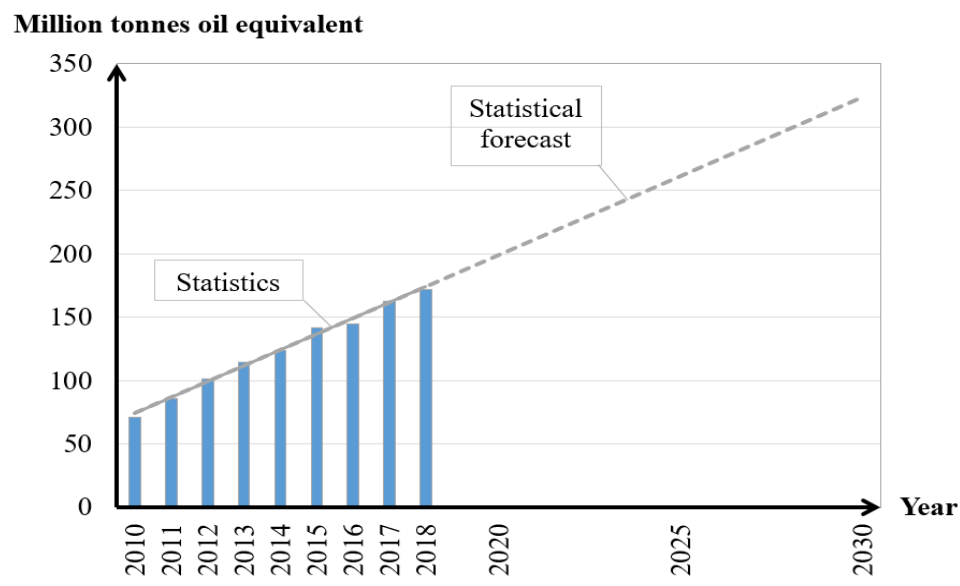

Figure 1: Development of renewable energy in Europe with a forecast until 2030 (according to information of the British Petroleum).

For example, labor [16] emphasizes the problem of energy consumption in Ukraine in the field of construction. In mathematical modelling of the thermal regime of houses, a systematic approach prevails in which the house is considered as a single energy system consisting of interdependent elements. As a result, the paper presents functional equations for optimizing the shape of a General body that is located in an arbitrary radiation thermal field. In addition, the improvement of structures with mathematical modelling of heat exchange in heat exchangers of ventilation systems of energy-saving buildings was carried out [17].

Taking into account the development trend of renewable energy in Ukraine and the need for its development in the field of construction, there are works that offer designs of solar collectors combined with the exterior fences of the building. For example, the work of a wall solar collector on labor [18], with a frame housing, which is installed on a transparent (glass) surface, mounted in the external fence of the building. Or the construction of a solar wall, where the solar collector for the needs of heat supply is integrated into the wall of the building.

However, such structures are not provided for buildings with an increased area of the glass facade.

\section{The Main Material}

Taking into account the development of renewable energy in Ukraine and the construction of glass facades, it was proposed to combine the solar collector with the glass facade of the building while integrating it into the glass fence. Studies of the proposed installation were carried out for the mode of natural circulation of the heat carrier and for the intensity of simulated solar radiation of $300 \mathrm{~W} / \mathrm{m}^{2}$.

The experimental solar heat supply system worked according to the following scheme: the heat carrier enters the storage tank; when opening and setting up the shut-off and adjustment 
valves, the water enters the solar collector, is heated by solar energy and moves back to the storage tank according to the principle of natural convection (Fig. 2).

The main, invariable, conditions of research were:

1 - the system, before each study, was filled with a fresh portion of water;

2 - air was being removed from the system;

3 - the intensity of the solar energy flow was measured using a pyranometer;

4 - the temperature of the heat carrier was measured by mercury thermometers at three points in the system (at the outlet of the solar collector, at the inlet to the collector, and in the storage tank);

5 - the ambient temperature and its speed were measured by a thermoelectro anemometer TESTO $405-$ V1.

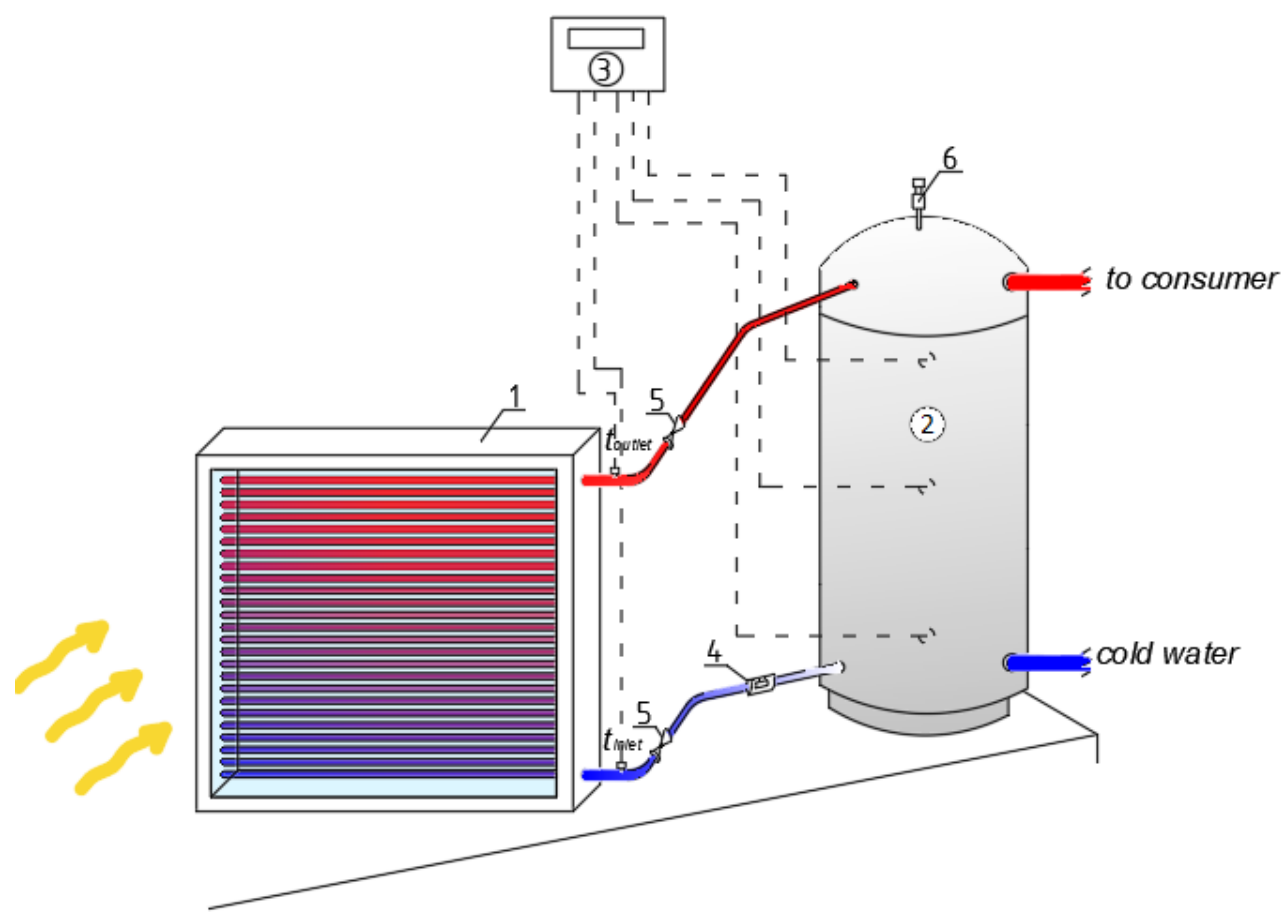

Figure 2: Experimental solar heating system in which solar collector is combined with the glass facade of the building, where 1 - the solar collector 2 - the storage tank of the heat energy 3 - display of gathering information from the temperature sensors, 4 - the check valve 5 - shut-off and control valves, 6 - panel security of the system solar heating

The temperature change of the carrier heat at the inlet and outlet from the solar collector is shown in Fig. 3. In addition, in Fig. 3 shows data on changes in the ambient temperature. It was found that the intensity of the simulated solar radiation flow $300 \mathrm{~W} / \mathrm{m}^{2}$, the temperature at the outlet of the solar collector reached $41^{\circ} \mathrm{C}$, which is about $50 \%$ higher than the temperature at the inlet to it. 


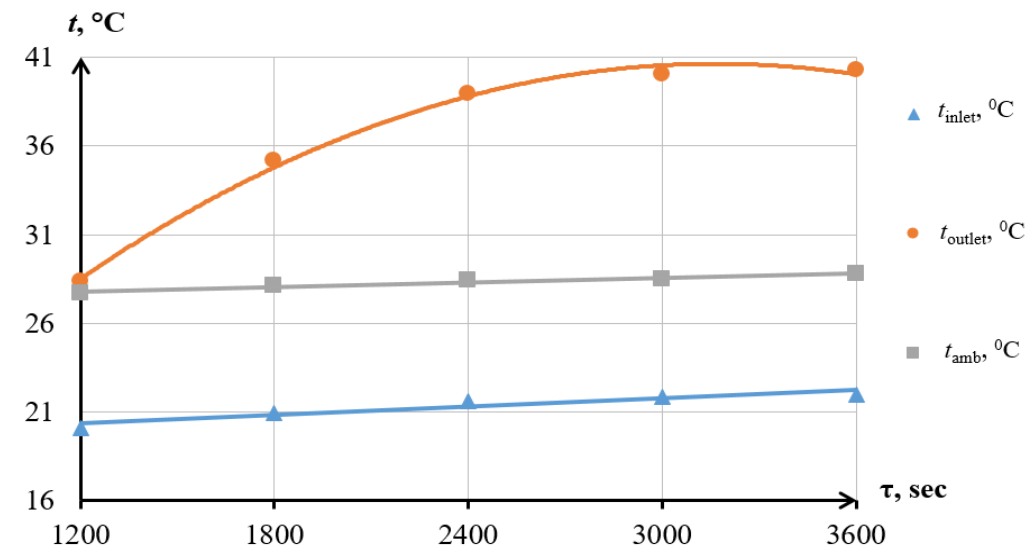

Figure 3: Determining the temperature change of the heat carrier during the experiment at the inlet and outlet of the solar collector, which is combined with the glass facade of the building

In Fig. 4 data on changes in the temperature of the heat carrier in the thermal energy storage tank during experimental studies are presented. It could be seen that the temperature of the heat carrier in the solar heat transfer system in the mode of natural circulation of the heat carrier on average reached $20.5^{\circ} \mathrm{C}$.

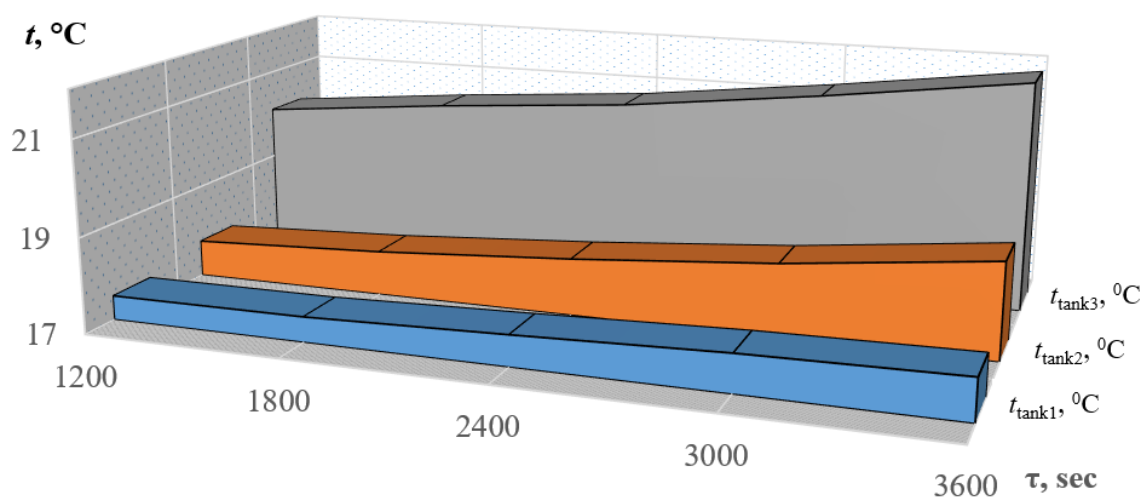

Figure 4: Investigation of changes in the temperature of the heat carrier during experimental studies in the heat energy storage tank

The amount of heat energy from solar radiation entering on the solar collector is a function of the intensity and time (1):

$$
Q=f(I, \tau)
$$

where: $\mathrm{Q}$ - the amount of heat energy from solar radiation entering on the collector, $\mathrm{kJ} / \mathrm{m}^{2}$; I - intensity of solar energy entering on the solar collector plane, $\mathrm{W} / \mathrm{m}^{2} ; \tau$ - time of the experiment, sec.

The change in the average specific maximum heat energy stored in the storage tank is graphically shown in Fig. 5. Moreover, the data of thermal energy that was received with the 
intensity of simulated solar radiation to the surface of the solar collector with accumulation are given. Averaging the results obtained, it can be established that the difference between the obtained parameters is $\approx 57 \%$.

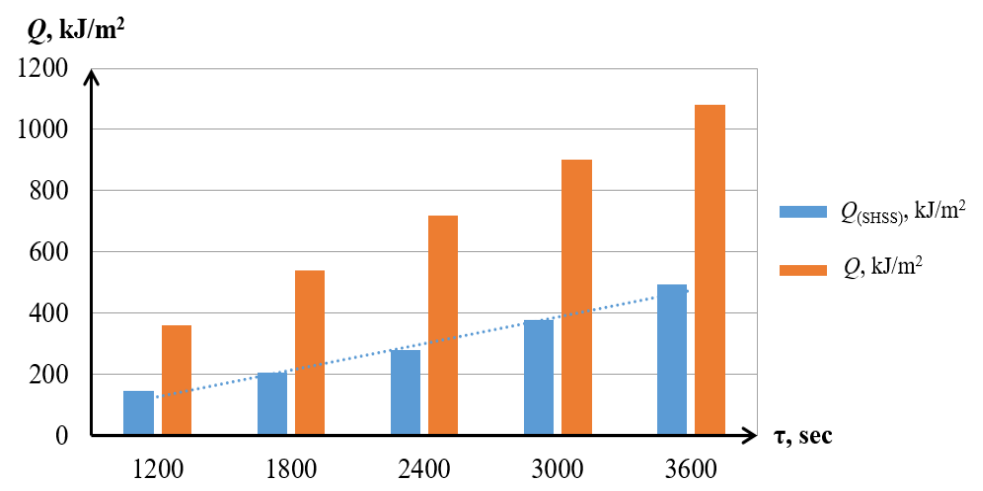

Figure 5: Changes in the thermal energy stored in the storage tank Q(SHSS) and the amount of simulated solar radiation received on the surface of the solar collector in time with accumulation $\mathrm{Q}$.

Analyzing the efficiency of a solar heat supply system (SHSS) with a solar collector in the mode of natural circulation of the heat carrier, the efficiency coefficient reached an average of $46 \%$. It is worth noting that the change in the thermal efficiency of the solar heat supply system ПSHSS with a solar collector takes an increasing trend (Fig. 6).

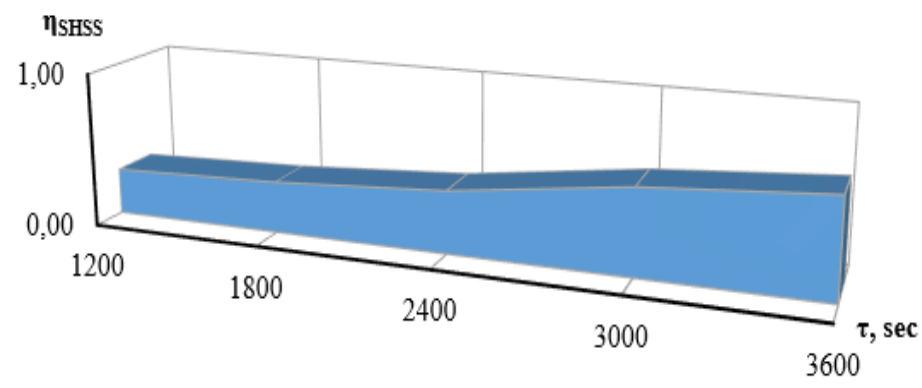

Figure 6: Establishing the efficiency of the solar heat supply system during the experiment with the collector integrated into the glass facade of the building

Therefore, the experimental model of the combined solar heat supply system in the mode of natural circulation of the heat carrier is effective for providing a building with a lowtemperature carrier. The heat of the carrier is heated for an hour by an average of $15^{\circ} \mathrm{C}$.

\section{Conclusions}

It is established that for European countries the capacity of installations using renewable energy sources may exceed 300 million tons of oil equivalent by 2030 . One of the most promising energy sources is solar energy, which is confirmed by the growth in the development of renewable energy for European countries. Since the territory of Europe has sufficient potential for renewable energy sources, this is a prerequisite for the widespread 
introduction of solar collectors in the solar energy industry.

Experimentally determined thermal parameters of solar heating designed for the solar collector provided an opportunity to develop methods of engineering calculation, allowing even at the stage of implementation of the solar collector install, what would be the temperature of the heat carrier in the solar heating for its intended use. The heat of the carrier is heated for an hour by an average of $15^{\circ} \mathrm{C}$. According to engineering calculations of the solar heat supply system, it becomes possible to choose the most optimal mode of operation with the solar collector integrated into the translucent facade of the building based on the variable intensity of simulated solar radiation.

It is investigated that the amount of specific heat energy accumulated in the heat storage tank takes an increasing trend with the highest average maximum value of $\approx 490 \mathrm{~kJ} / \mathrm{m}^{2}$. The efficiency of the solar heat supply system with the developed solar collector integrated into the glass facade of the building is on average $46 \%$.

\section{Acknowledgements}

This article was elaborated in the framework of the project VEGA 1/0697/17.

\section{References}

[1] Shapoval S., Venhryn I. (2014) Prospects for using solar energy in Ukraine. Young scientist, 7(2), 21-24. (in Ukrainian)

[2] Bockris J., Veziroglu T., Smith D. (2006) Solar hydrogen energy. The power to save the Earth. Macdonald Optima, London, 168. (in Ukrainian)

[3] Shapoval S. (2016) The efficiency of combined solar collectors for energy efficient buildings. Budownictwo o Zoptymalizowanym Potencjale Energetycznym 2(18), 81-86. (in English)

[4] Shapoval S. (2017) Economic efficiency of application of solar window. Czasopismo inzynierii ladowej, srodowiska i architektury journal of civil engineering, Environment and architecture, (2/II/17), 123-132. (in English)

[5] Lahutin O., Shmakov I., Nikulin Yu. (2008) Albedo of the underlying surface according to the MODIS/Terra Spectroradiometer. Sixth all-Russian open annual conference " Modern problems of remote sensing of the Earth from space», 12. (in Russian)

[6] Rekstad J., Meir M., Murtnes E., Dursun A. (2015) A comparison of the energy consumption in two passive houses, one with a solar heating system and one with an air-water heat pump. Energy and Buildings, 96, 149-161. (in English)

[7] Kazakov H. (2009) Architecture of energy-saving solar houses. Lviv Polytechnic, 84. (in Ukrainian)

[8] Kazakov H. (2012) Solar houses: typological classification. Bulletin of the National University "Lviv Polytechnic", 728, 235-240. (in Ukrainian)

[9] Shapoval, S., Zhelykh, V., Venhryn, I., Kozak, K., \& Krygul, R. (2019). Theoretical and experimental analysis of solar enclosure as part of energy-efficient house. Eastern-European Journal of Enterprise Technologies, 2(8-98), 38-45. doi:10.15587/1729-4061.2019.160882 (in English)

[10] Hromova U. (2012) Environmental problems as prerequisites for the development of energysaving technologies. Poultry Market. (in Russian) 
[11] Pashchenko N. (2013) Energy-efficient and energy-saving policy of Poland. Reports of participants. Charitable foundation Havrylyshyna B., 8. (in Ukrainian)

[12] Basok B., Fareniuk H. (2014) Conceptual foundations for creating an experimental passive-type house (with a total area of 300 square meters). Building construction, 81, 233-243. (in Ukrainian)

[13] Basok B., Bozhko K., Bieliaieva T. (2014) Polyvalent heat supply system for an experimental house of passive type $(300 \mathrm{~m} 2)$ based on the use of renewable and alternative energy sources. Science and innovation. Institute of technical Thermophysics of the national Academy of Sciences of Ukraine, 6(10), 34-51. (in Ukrainian)

[14] Dvoretskyi A. (2013) Design features of energy-efficient buildings in the South of Ukraine. Construction, Materials science, Engineering, 68, 125-129. (in Russian)

[15] BP Statistical Review of World Energy 2019. (2019). Centre for Energy Economics Research and Policy, Heriot-Watt University, 61. (in English)

[16] Serheichuk O. (2008) Geometric modeling of physical processes when optimizing the shape of energy-efficient houses (Doctoral dissertation), Kyiv, 425. (in Ukrainian)

[17] Horobets V., Masiuk M. (2016) Development of a new design and mathematical modeling of heat and mass transfer processes for heat exchangers of ventilation systems of an energy-saving house. Energy and automation, 1, 90-98. (in Ukrainian)

[18] Chulkov D. (2007). Patent of Ukraine 26650. Kyiv: State Patent Office of Ukraine. (in Ukrainian)

[19] Shapoval, S. (2017). Patent of Ukraine 113688. Kyiv: State Patent Office of Ukraine. (in Ukrainian)

[20] Shapoval, S., Zhelykh, V., Spodyniuk, N., Dzeryn, O., \& Gulai, B. (2019). The effectiveness to use the distribution manifold in the construction of the solar wall for the conditions of circulation. Pollack Periodica, 14(2), 143-154.

[21] Lukáč, P., Horbaj, P. (2015) Some notes to design of heating and hot water supply system like a power of low-temperature heating utilization in combination with solar collectors in housing and municipal sphere. Cassotherm 2015. TU v Košiciach, 321-331. ISBN 978-80-553-2438-8. 